\title{
An example of a possible leech-bryozoan association in freshwater
}

\author{
Anna L. Klass',2, Svetlana E. Sokolova², Alexander V. Kondakov',2, \\ Yulia V. Bespalaya ${ }^{1,2}$, Mikhail Yu. Gofarov',2, Alena A. Tomilova ${ }^{2}$, \\ Ilya V. Vikhrev ${ }^{1,2}$, Ivan N. Bolotov ${ }^{1,2}$
}

I Northern Arctic Federal University, Arkhangelsk, Russia 2 N. Laverov Federal Center for Integrated Arctic Research, Russian Academy of Sciences, Arkhangelsk, Russia

Corresponding author: Anna L. Klass (ania.klass29@gmail.com)

Academic editor: F. Govedich | Received 30 June 2018 | Accepted 17 September 2018 | Published 1 November 2018

http://zoobank.org/1DB04CFA-EE3F-4D7D-B6B0-826BB75A6BB2

Citation: Klass AL, Sokolova SE, Kondakov AV, Bespalaya YV, Gofarov MY, Tomilova AA, Vikhrev IV, Bolotov IN (2018) An example of a possible leech-bryozoan association in freshwater. ZooKeys 794: 23-30. https://doi. org/10.3897/zookeys.794.28088

\begin{abstract}
Associations of various invertebrate species with bryozoans and sponges are a well-known marine phenomenon but such epizooic communities are far less diverse in freshwater environments. Here an occurrence of numerous leeches Alboglossiphonia cf. papillosa (Braun, 1805), in interstitial spaces between zooids of a colony of the freshwater bryozoan species Plumatella aff. fungosa (Pallas, 1768) in Eastern Siberia is described. To the best of our knowledge, this record appears to be the first known example of a leech-bryozoan association, although such relationships deserve further research.
\end{abstract}

\section{Keywords}

Bryozoa, bryozoan-associated epibionts, eastern Siberia, Glossiphoniidae, Hirudinea, Plumatellidae

\section{Introduction}

Marine ecosystems share numerous examples of commensal associations of various invertebrate taxa with sedentary animals such as bryozoans and sponges (Ristedt and Schuhmacher 1985, Wulff 2006). In contrast, the diversity of bryozoan- and spongeassociated epibionts in freshwater is much lower. For example, only a single freshwater

Copyright Anna L. Klass et al. This is an open access article distributed under the terms of the Creative Commons Attribution License (CC BY 4.0), which permits unrestricted use, distribution, and reproduction in any medium, provided the original author and source are credited. 
shrimp-sponge association has been described so far (Rintelen et al. 2007), while multiple examples of such associations are known from the marine environment (Macdonald et al. 2006). Larvae of a few aquatic insects use freshwater sponges and bryozoans as a food source (Resh 1976, Ricciardi and Reiswig 1994), and several mites (Acari: Unionicolidae) occur in parasitic association with freshwater sponges (Edwards and Vidrine 2006). Freshwater bryozoans were found in association with an assemblage of filter feeders, including other bryozoans, sponges, hydroids, and caddisfly larvae (Ricciardi and Reiswig 1994). The interstitial spaces between zooids and around the edges of colonies may be occupied by several invertebrate taxa, i.e. tubicolous rotifers, ostracods, naidid oligochaetes, nematodes, and chironomids (Ricciardi and Reiswig 1994).

Here we describe an occurrence of numerous leeches, Alboglossiphonia cf. papillosa (Braun, 1805) inhabiting interstitial spaces between zooids of a colony of freshwater bryozoan species Plumatella aff. fungosa (Pallas, 1768). We present the results of a molecular and morphological study of both the leech and the bryozoan species and briefly discuss possible explanations of this unusual finding. To the best of our knowledge, it represents the first documented case of a possible leech-bryozoan association.

\section{Materials and methods}

A fragment of a willow branch with a bryozoan colony was collected by hand in a shallow coastal site of a floodplain lake in the Lena River basin, Yakutia, Eastern Siberia, Russia (Figure 1). This sample was preserved in $96 \%$ ethanol immediately after collecting. Leech specimens were collected and counted both from the ethanol solution in the vial and from interstitial spaces between the zooids on the basis of careful investigation of the colony under a stereomicroscope (Leica EZ 4D, Leica Microsystems, Germany). The total length of body in each leech specimen was measured using ocular micrometer of the same stereomicroscope.

Total genomic DNA was extracted from 96\% ethanol-preserved tissue samples using the NucleoSpin Tissue Kit (Macherey-Nagel GmbH \& Co. KG, Germany), following the manufacturer's protocol. For molecular analyses we obtained partial sequences of the following markers: the mitochondrial cytochrome $c$ oxidase subunit I gene (COI), the nuclear $18 \mathrm{~S}$ ribosomal RNA (18S rRNA) and 28S ribosomal RNA (28S rRNA) genes. We amplified partial sequences of the COI and $18 \mathrm{~S}$ rRNA genes for Alboglossiphonia cf. papillosa and partial sequences of the COI and $28 \mathrm{~S}$ rRNA genes for Plumatella aff. fungosa using standard primers (Tables 1,2). The PCR mix contained approximately $200 \mathrm{ng}$ of total cell DNA, $10 \mathrm{pmol}$ of each primer, $200 \mu \mathrm{mol}$ of each dNTP, $2.5 \mu \mathrm{l}$ of PCR buffer (with $10 \times 2 \mathrm{mmol} \mathrm{MgCl}_{2}$ ), 0.8 units Taq DNA polymerase (SibEnzyme Ltd.), and $\mathrm{H}_{2} \mathrm{O}$ was added for a final volume of $25 \mu \mathrm{l}$. Thermocycling was implemented with marker-specific PCR programs as follows: (i) COI: $95^{\circ} \mathrm{C}$ ( $\left.4 \mathrm{~min}\right)$, followed by 32 cycles at $94^{\circ} \mathrm{C}(50 \mathrm{sec}), 50^{\circ} \mathrm{C}(50 \mathrm{sec}), 72^{\circ} \mathrm{C}(50 \mathrm{sec})$ and a final extension at $72{ }^{\circ} \mathrm{C}(5 \mathrm{~min})$; (ii) $28 \mathrm{~S}$ rRNA: $95^{\circ} \mathrm{C}(4 \mathrm{~min})$, followed by 22 


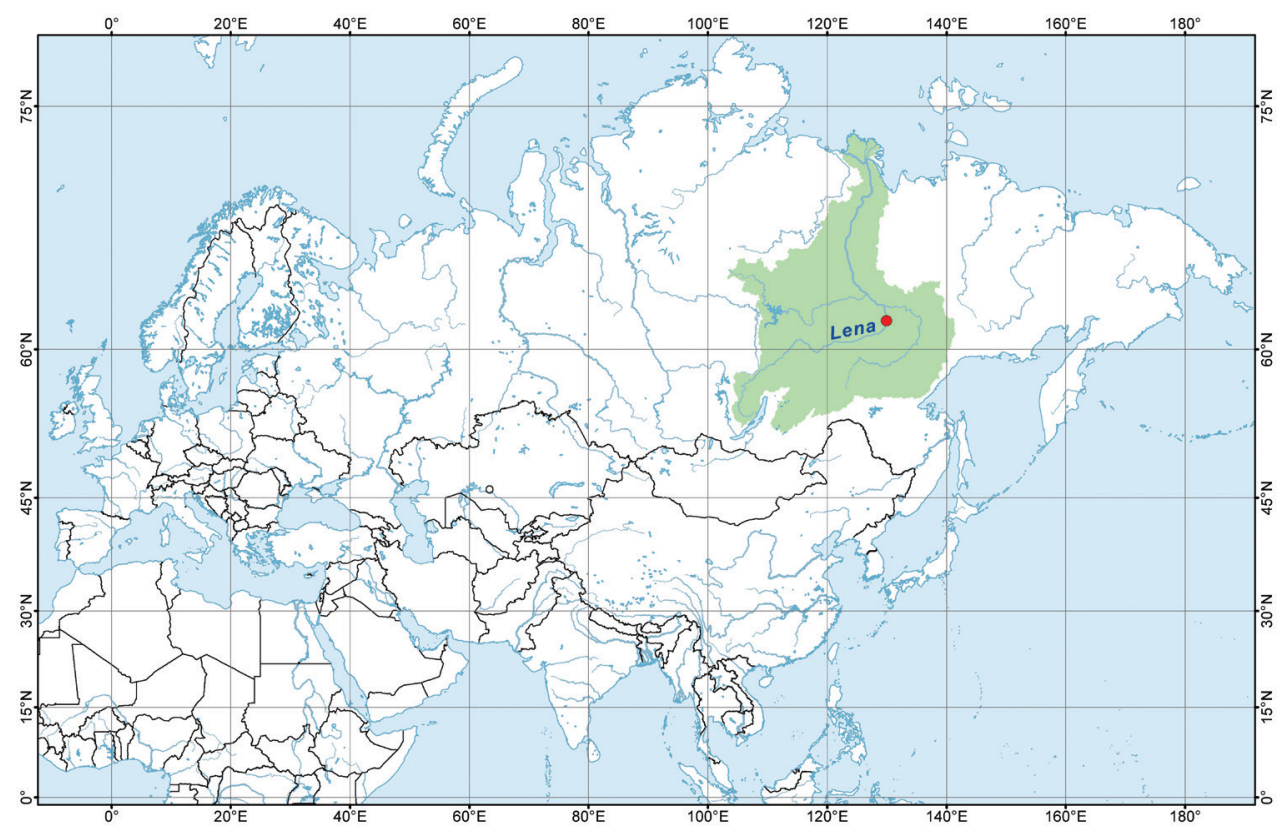

Figure I. Map of Lena River basin, Eastern Siberia, with occurrence of the leech-bryozoan association in a floodplain lake (red dot).

Table I. List of sequenced specimens of Alboglossiphonia cf. papillosa and Plumatella aff. fungosa from Eastern Siberia (a floodplain lake in the Lena River basin).

\begin{tabular}{c|c|c|c|c}
\hline Species & Specimen Voucher* & COI acc. no. & 18S $\boldsymbol{r}$ RNA acc. no. & 28S $\boldsymbol{r} \boldsymbol{R N A}$ acc. no. \\
\hline \multirow{4}{*}{ Alboglossiphonia cf. papillosa } & Hir13/1 & $\mathrm{MH} 286267$ & $\mathrm{MH} 286273$ & $\mathrm{n} / \mathrm{a}$ \\
\cline { 2 - 5 } & $\mathrm{Hir} 13 / 2$ & $\mathrm{MH} 286268$ & $\mathrm{n} / \mathrm{a}$ & $\mathrm{n} / \mathrm{a}$ \\
\cline { 2 - 5 } & $\mathrm{Hir} 13 / 3$ & $\mathrm{MH} 286269$ & $\mathrm{n} / \mathrm{a}$ & $\mathrm{n} / \mathrm{a}$ \\
\cline { 2 - 5 } & $\mathrm{Hir} 13 / 4$ & $\mathrm{MH} 286270$ & $\mathrm{MH} 286274$ & $\mathrm{n} / \mathrm{a}$ \\
\cline { 2 - 5 } & $\mathrm{Hir} 13 / 5$ & $\mathrm{MH} 286271$ & $\mathrm{MH} 286275$ & $\mathrm{n} / \mathrm{a}$ \\
\hline Plumatella aff. fungosa & Por02 & $\mathrm{MH} 286272$ & $\mathrm{n} / \mathrm{a}$ & $\mathrm{MH} 286276$ \\
\hline
\end{tabular}

*Materials are deposited in the Russian Museum of Biodiversity Hotspots (RMBH), Institute of Biogeography and Genetic Resources, Federal Center for Integrated Arctic Research of the Russian Academy of Sciences (Arkhangelsk, Russia).

cycles at $94^{\circ} \mathrm{C}(50 \mathrm{sec}), 60{ }^{\circ} \mathrm{C}(50 \mathrm{sec}), 72^{\circ} \mathrm{C}(50 \mathrm{sec})$, and a final extension at $72{ }^{\circ} \mathrm{C}$ $(5 \mathrm{~min})$; (iii) $18 S \mathrm{rRNA}: 95^{\circ} \mathrm{C}(4 \mathrm{~min})$, followed by $28-31$ cycles at $94^{\circ} \mathrm{C}(50 \mathrm{sec})$, $64{ }^{\circ} \mathrm{C}(50 \mathrm{sec}), 72{ }^{\circ} \mathrm{C}(50 \mathrm{sec})$ and a final extension at $72{ }^{\circ} \mathrm{C}(5 \mathrm{~min})$. Forward and reverse sequence reactions were performed directly on purified PCR products using an $\mathrm{ABI} \mathrm{PRISM}^{\oplus}$ BigDye $^{\mathrm{TM}}$ Terminator v. 3.1 reagents kit and run on an ABI PRISM ${ }^{\odot}$ 3730 DNA analyzer (Thermo Fisher Scientific Inc., Waltham, MA, USA). The resulting sequences were checked by eye with BioEdit v. 7.2.5 (Hall 1999). 
Table 2. Primer sequences for PCR amplification and sequencing.

\begin{tabular}{|c|c|c|c|c|}
\hline Gene fragment & Primer's name & Direction & Sequence (5'-3') & Reference \\
\hline \multirow[t]{2}{*}{ COI } & LoboF1 & Forward & kbtchacaaaycayaargayathgg & \multirow[t]{2}{*}{ Lobo et al. (2013) } \\
\hline & LoboR1 & Reverse & taaacytcwggrtgwccraaraayca & \\
\hline \multirow[t]{6}{*}{$18 \mathrm{~S}$ rRNA } & $1 \mathrm{~F}$ & Forward & tacctggttgatcctgccagtag & \multirow[t]{3}{*}{ Giribet et al. (1996) } \\
\hline & $4 \mathrm{R}$ & Reverse & gaattaccgcggctgctgg & \\
\hline & $3 \mathrm{~F}$ & Forward & gttcgattccggagaggga & \\
\hline & 18Sbi & Reverse & gagtctcgttcgttatcgga & \multirow[t]{2}{*}{ Whiting et al. (1997) } \\
\hline & $18 \mathrm{Sa} 2.0$ & Forward & atggttgcaaagctgaaac & \\
\hline & $9 \mathrm{R}$ & Reverse & gatccttccgcaggttcacctac & Giribet et al. (1996) \\
\hline \multirow[t]{2}{*}{$28 \mathrm{~S}$ rRNA } & $\mathrm{D} 23 \mathrm{~F}$ & Forward & gagagttcaagagtacgtg & Park and Ó'Foighil (2000) \\
\hline & D2 & Reverse & tccgtgtttcaagacgg & Jovelin and Justine (2001) \\
\hline
\end{tabular}

\section{Results}

A bryozoan colony (size of $40 \times 20 \times 25 \mathrm{~mm}$ ) from Yakutia was heavily invaded by leeches. Twenty-five leeches (Figure 2A, C, D) were found in the interstitial spaces between zooids of this small colony. The living leeches were in spaces between zooids and were not visible externally when first collected (Figure 2A). The mean length of ethanol-preserved leeches ( \pm s.e.m.) in the sample is $3.9 \pm 0.2 \mathrm{~mm}(\min -\max =2.1-6.1 \mathrm{~mm} ; N=25)$. The sample includes 10 relatively large specimens of $\geq 4 \mathrm{~mm}$ long ( $40 \%$ of the total sample) (Figure $2 \mathrm{~B}$ ).

The results of molecular and morphological studies reveal that the leeches belong to Alboglossiphonia cf. papillosa (Braun, 1805), while the bryozoan species was identified as Plumatella aff. fungosa (Pallas, 1768).

\section{Taxonomy}

Phylum Annelida Lamarck, 1809

Subclass Hirudinea Linnaeus, 1758

Family Glossiphoniidae Vaillant, 1890

Genus Alboglossiphonia Lukin, 1976

\section{Alboglossiphonia cf. papillosa (Braun, 1805)}

Material examined. RUSSIA: Eastern Siberia, Yakutia, a floodplain lake of the Lena River near the city of Yakutsk, $62.3076^{\circ} \mathrm{N}, 129.8999^{\circ} \mathrm{E}, 25$ specimens from interstitial spaces between zooids of a Plumatella aff. fungosa colony, Bolotov leg. (voucher no. RMBH: Hir13).

Comments. Current taxonomy of this leech genus is uncertain. Closely related specimens of Alboglossiphonia cf. papillosa with homologous or very similar COI gene sequence (acc. nos. KM095100 and KM095101) (uncorrected $p$-distance $<1 \%$ ) were collected from the Gusinoye Lake, Yenisei Basin, Eastern Siberia (Kaygorodova et al. 2014). The BLAST search with the $18 S$ rRNA gene sequence returns the nearest members among the Alboglossiphonia taxa from the USA (acc. nos. AF115983 and AY962410) (Apakupakul et al. 1999; Siddall et al. 2005). 


\section{Phylum Bryozoa Ehrenberg, 1831 \\ Class Phylactolaemata Allman, 1856 \\ Family Plumatellidae Allman, 1856 \\ Genus Plumatella Lamarck, 1816}

\section{Plumatella aff. fungosa (Pallas, 1768)}

Material examined. RUSSIA: Eastern Siberia, Yakutia, a floodplain lake of the Lena River near the city of Yakutsk, $62.3076^{\circ} \mathrm{N}, 129.8999^{\circ} \mathrm{E}$, colony (size of $40 \times 20 \times 25$ $\mathrm{mm}$ ) on a willow branch fragment, Bolotov leg. (voucher no. RMBH: Por02).

Comments. The species phylogenetically relates to Plumatella fungosa from Estonia (acc. no. KF805632) (Dash and Vasemägi 2014), but with a low similarity (uncorrected $p$-distance 3.8\%). However, our specimen has 100\% accordance with Plumatella fungosa from Austria (acc. no. KC462027) (Hartikainen et al. 2013) by the nuclear $28 \mathrm{~S}$ rRNA gene sequence.

\section{Discussion}

To the best of our knowledge, leeches have not previously been found in association with freshwater bryozoans, although the specific bryozoan colonial structure provides microscopic spaces between zooids supporting suitable microhabitats for diverse epizooic invertebrate communities (Ricciardi and Reiswig 1994, Bushnell and Rao 1979). Possible causes of leech aggregation within a bryozoan colony recorded by us are unclear. Possible explanations of this unusual finding could include: first, leeches may simply use bryozoans as a shelter. Second, they may also use zooids as a suitable food source, although there are no published observations of this. Third, leeches may be attracted by and feed on other animals inhabiting interstitial spaces between the zooids, e.g., oligochaetes and chironomids, although such animals were virtually absent within this colony. Another possible explanation is that the leeches concentrated within a bryozoan colony because they were recently hatched from the same parent located near this colony. However, the latter hypothesis seems to be unlikely, because Alboglossiphonia cf. papillosa is a small species, the length of which rarely extends 7-8 $\mathrm{mm}$, and adult leeches of smaller size often occur (Lukin 1976). With respect to this, most of the leeches in our sample appear to be adults based on their size, and the shorter lengths of our ethanol-preserved specimens compared to the longer lengths of living leeches measured by Lukin (1976) can be accounted for by the fact that leeches contract in size when preserved.

Although this is the first recorded instance of a leech-bryozoan association, it may represent a largely overlooked phenomenon because of the hidden lifestyle of these small leeches. For example, the Japanese mussel leech Batracobdella kasmiana (Oka, 1910), which has a hidden life style within the mantle cavity of freshwater mussels, has only recently been discovered in the Russian Far East (Bolotov et al. 2017). 

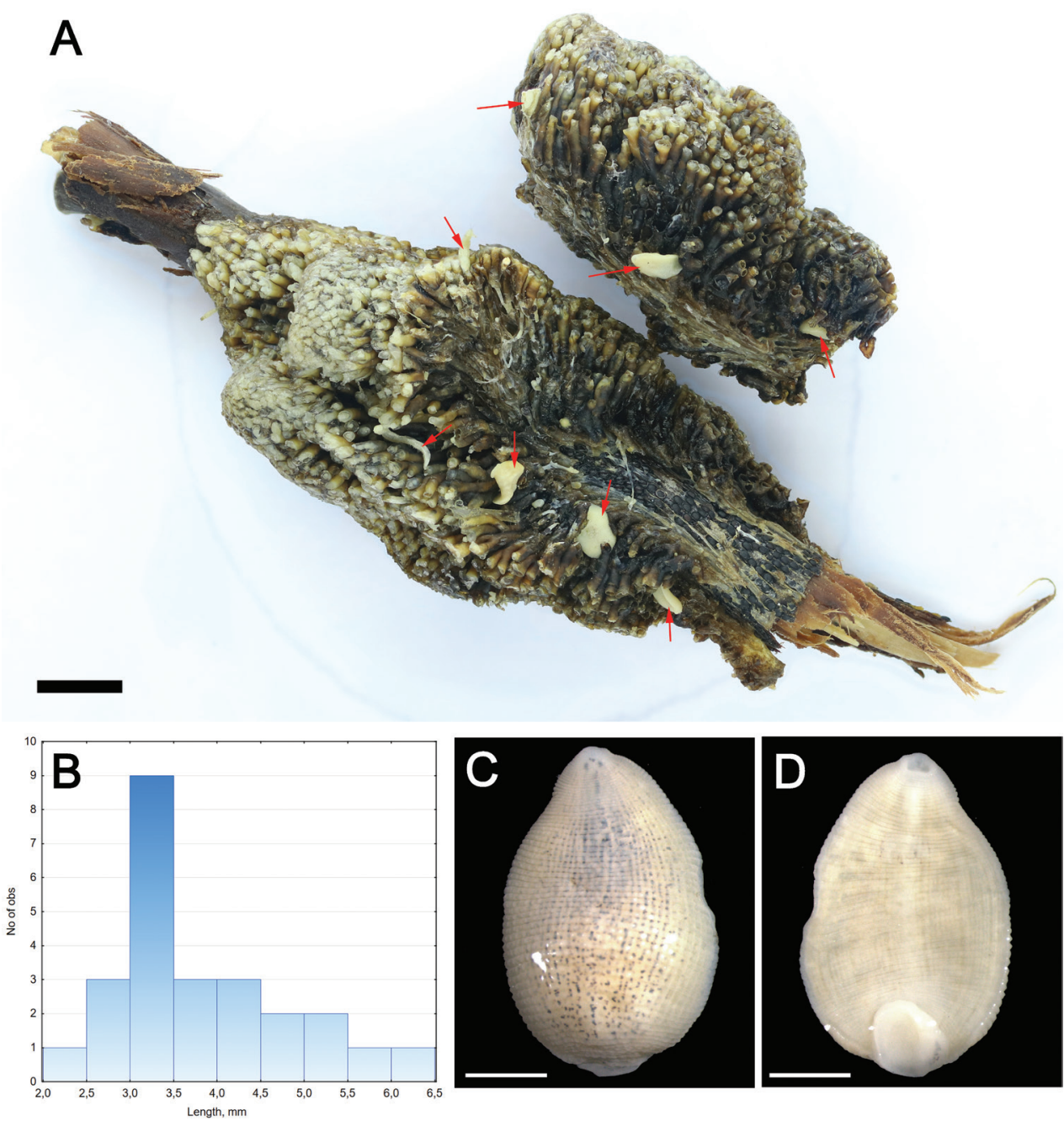

Figure 2. Leech-bryozoan association from a floodplain lake in Lena River basin, Yakutia, Eastern Siberia, Russia. A Leeches Alboglossiphonia cf. papillosa in interstitial spaces between zooids of a Plumatella aff. fungosa colony (ethanol-preserved sample). The red arrows indicate leech specimens. B Size frequency histogram of the leech sample $(N=25)$. C Dorsal and $\mathbf{D}$ Ventral view of adult leech. Photographs Svetlana E. Sokolova. Scale bars: $5 \mathrm{~mm}(\mathbf{A}) ; 1 \mathrm{~mm}(\mathbf{C}, \mathbf{D})$.

\section{Acknowledgements}

This work was partly funded by grants from the Russian Ministry of Education and Science (project nos. 6.2343.2017/4.6), Federal Agency for Scientific Organizations (project nos. 0409-2016-0022 and 0409-2015-0143), Russian Foundation for Basic Research, RFBR (project nos. 16-34-60152, and 17-45-290066) and the program of Presidium Ural Branch of RAS (no. 0409-2018-0148). 


\section{References}

Apakupakul K, Siddall ME, Burreson EM (1999) Higher level relationships of leeches (Annelida: Clitellata: Euhirudinea) based on morphology and gene sequences. Molecular Phylogenetics and Evolution 12: 350-359. https://doi.org/10.1006/mpev.1999.0639

Bolotov IN, Vikhrev IV, Aksenova OV, Bespalaya YV, Gofarov MY, Kondakov AV, Sokolova SE (2017) Discovery and natural history of the mussel leech Batracobdella kasmiana (Oka, 1910) (Hirudinida: Glossiphoniidae) in Russia. Zootaxa 4319: 386-390. https://doi. org/10.11646/Zootaxa.4319.2.11

Bushnell JH, Rao KS (1979) Freshwater Bryozoa: microarchitecture of statoblasts and some aufwuchs animal associations. In: Larwood GP, Abbott MB (Eds) Advances in Bryozoology. Academic Press, London, 75-92.

Dash M, Vasemägi A (2014) Proliferative kidney disease (PKD) agent Tetracapsuloides bryosalmonae in brown trout populations in Estonia. Diseases of Aquatic Organisms 109: 139-148. https://doi.org/10.3354/dao02731

Edwards DD, Vidrine MF (2006) Host specificity among Unionicola spp. (Acari: Unionicolidae) parasitizing freshwater mussels. Journal of Parasitology 92: 977-983. https://doi. org/10.1645/GE-3565.1

Giribet G, Carranza S, Baguna J, Riutort M, Ribera C (1996) First molecular evidence for the existence of a Tardigrada+ Arthropoda clade. Molecular Biology and Evolution 13: 76-84. https://doi.org/10.1093/oxfordjournals.molbev.a025573

Hall TA (1999) BioEdit: A user-friendly biological sequence alignment editor and analysis program for Windows 95/98/NT. Nucleic Acids Symposium Series 41: 95-98.

Hartikainen H, Waeschenbach A, Wöss E, Wood T, Okamura B (2013) Divergence and species discrimination in freshwater bryozoans (Bryozoa: Phylactolaemata). Zoological Journal of the Linnean Society 168: 61-80. https://doi.org/10.1111/zoj.12025

Jovelin R, Justine JL (2001) Phylogenetic relationships within the polyopisthocotylean monogeneans (Platyhelminthes) inferred from partial $28 \mathrm{~S}$ rDNA sequences. International Journal for Parasitology 31: 393-401. https://doi.org/10.1016/S00207519(01)00114-X

Kaygorodova IA, Mandzyak N, Petryaeva E, Pronin NM (2014) Genetic diversity of freshwater leeches in Lake Gusinoe (Eastern Siberia, Russia). The Scientific World Journal 2014: 619127. https://doi.org/10.1155/2014/619127

Lobo J, Costa PM, Teixeira MA, Ferreira MS, Costa MH, Costa FO (2013) Enhanced primers for amplification of DNA barcodes from a broad range of marine metazoans. BMC Ecology 13: 34. https://doi.org/10.1186/1472-6785-13-34

Lukin EI (1976) Leeches of fresh and brackish water bodies. Fauna of the USSR 109: 1-484.

Macdonald KS, Ríos R, Duffy JE (2006) Biodiversity, host specificity, and dominance by eusocial species among sponge-dwelling alpheid shrimp on the Belize Barrier Reef. Diversity and Distributions 12: 165-178.

Park JK, Ó'Foighil D (2000) Sphaeriid and Corbiculid Clams Represent Separate Heterodont Bivalve Radiations into Freshwater Environments. Molecular Phylogenetics and Evolution 14: 75-88. https://doi.org/10.1006/mpev.1999.0691 
Resh VH (1976) Life cycles of invertebrate predators of freshwater sponge. In: Harrison FW, Cowden RR (Eds) Aspects of Sponge Biology. Academic Press, London, 299-314. https:// doi.org/10.1016/B978-0-12-327950-7.50025-7

Ricciardi A, Reiswig HM (1994) Taxonomy, distribution, and ecology of the freshwater bryozoans (Ectoprocta) of eastern Canada. Canadian Journal of Zoology 72: 339-359. https:// doi.org/10.1139/z94-048

Rintelen Kv, Rintelen Tv, Meixner M, Lüter C, Cai Y, Glaubrecht M (2007) Freshwater shrimp-sponge association from an ancient lake. Biology Letters 3: 262-264. https://doi. org/10.1098/rsbl.2006.0613

Ristedt H, Schuhmacher H (1985) The bryozoan Rhynchozoon larreyi (Audouin, 1826) - A successful competitor in coral reef communities of the Red Sea. Marine Ecology 6: 167179. https://doi.org/10.1111/j.1439-0485.1985.tb00136.x

Siddall ME, Budinoff RB, Borda E (2005) Phylogenetic evaluation of systematics and biogeography of the leech family Glossiphoniidae. Invertebrate Systematics 19: 105-112. https:// doi.org/10.1071/IS04034

Whiting MF, Carpenter JC, Wheeler QD, Wheeler WC (1997) The Strepsiptera problem: phylogeny of the holometabolous insect orders inferred from $18 \mathrm{~S}$ and $28 \mathrm{~S}$ ribosomal DNA sequences and morphology. Systematic Biology 46: 1-68. https://doi.org/10.1093/ sysbio/46.1.1

Wulff JL (2006) Ecological interactions of marine sponges. Canadian Journal of Zoology 84: 146-166. https://doi.org/10.1139/z06-019 